\title{
SOVYET DÖNEMININ İLK YILLARINDA KIRGIZISTAN'DA MILLÎ ÖZERK CUMHURIYET KURMA KONUSUNDAKI FIKRII MÜNAKAŞALAR
}

\author{
ANVARBEK MOKEEV* - ZUHRA ALTIMIŞOVA*
}

\section{GiRIŞ}

1920-1930'lu yllar, Sovyet tarihinde SSCB bünyesinde yer alan bütün halklarının sosyal yapılarını kökten değiştirme dönemi olarak bilinmektedir. Sovyet hükümeti, Türkistan'da siyasî, ekonomik ve kültürel alanlarda kurguladığg sosyalist modeli yerleştirmeye çalışmışır. Bu dönemde Bolşevikler, bölgedeki Türk halklarının 1917 Şubat devriminden sonra kurdukları çeşitli siyasî parti ve örgütlerini tasfiye etmiş ve güçlü bir merkezî yönetim sistemi oluşturmuşlardır. 1920'(li) -1930’lu yıllarda Kırgizların sosyal hayatı, boy teşkilatı üzerine kurulu yapısını muhafaza ediyor; Sovyetler, Kırgızları göçebe hayattan yerleşik hayata geçmeye zorlayarak, kolhoz sistemi kapsamında boy teşkilâtının izlerini yok etmeye çalışıyordu. Bu bağlamda Sovyet yönetimi, üst tabakaların etkilerini yok etmek için sinıf mücadelesi teorisini ortaya atarak fakirlerle zenginler arasindaki mücadeleyi körüklemiştir. Sınıf mücadelesi teorisi çerçevesinde sömüren ve sömürülen gruplar arasındaki mücadelenin kaçınılmazlı̆̆ı öğretisi Kırgız toplumunda da propaganda edilerek, fakir kesimleri yanlarına çekmeye ve zenginlere karşı acımasız bir savaş başlatmaya girişmişlerdir. Kırgız toplumunda bay ve manap ${ }^{1}$ olarak isimlendirilen zengin zümreler sömürücü sınıf olarak görülmüş ve yok edilmeleri hedeflenmiştir. Kezâ zenginlere karşı yoğun bir propaganda gerçekleştirilmiş; üst tabakaların etkilerini yok etmek için bunların bir kısmı Kırgızistan içinde farklı bölgelere, daha

\footnotetext{
Prof. Dr., Kırgızistan-Türkiye Manas Üniversitesi, Edebiyat Fakültesi, Tarih Bölümü, Bişkek/ KIRGIZISTAN, anvar.mokeev@manas.edu.kg

** Dr. Öğr. Üyesi., Kırgizistan-Türkiye Manas Üniversitesi, Edebiyat Fakültesi, Tarih Bölümü, Bişkek/ KIRGIZISTAN, zuura.altymyshova@manas.edu.kg

Bay, Kırgızistan'da 1917 Ekim İhtilali'ne kadar hayvanları, toprağı, kışlağı, yaylağı olan varlıklı sosyal tabakaya verilen addır. Manap ise, XVII. yüzylldan Sovyet yönetimine kadarki süre içerisinde Kırgizistan'ın kuzeyinde halkı yöneten boy reislerinin unvanlarıdır. Kırgızistan'ın güneyinde Manap unvanı kullanılmıyordu. Bu iki kelime veya unvan, Sovyet döneminde literatürde iş̧̧ smifi düşmanlan olarak görülen zengin kesimi tanımlamak için Bay-Manap şeklinde birleşik olarak kullanılmışır.
} 
üst seviyede nüfuzlu olanlar ise başka Sovyet cumhuriyetlerine sürgün edilmişlerdir. Ekonomide özel mülkiyet devletleştirilmiş, kolhoz ve sovhozlar kurulmuştur. Yine aynı şekilde kültür alanında bir Kültür Devrimi ${ }^{2}$ kampanyası başlatılmış, toplumun geleneksel din ve kültürünü bırakıp Sovyet kültürünü benimsemesi planlanmıştır.

$\dot{I}_{c}$ Savaşta $^{3}$ Sovyet ordusu (Kızıl Ordu) başarılı olduktan sonra Bolşeviklerin dikkati Batıdan Doğuya çevrilmiş; diğer bölgelerde olduğu gibi Lenin’in milletler politikası Türkistan'da da uygulanmaya çalışılmış ve tarihî Türkistan coğrafyası bölünerek her halkın yoğun olarak yaşadığı topraklar üzerinde SSCB bünyesinde özerk cumhuriyetler ve vilayetler oluşturulması siyaseti izlenmiştir. Bu siyasete karşı, T. Rıskulov gibi Türkistan’ın önde gelen aydınlarının birçoğunun, millî sınırların yeniden çizilmesine alternatif olarak Türk halklarını bir araya getiren birleşik bir Türk Sovyet Cumhuriyeti kurulmasını öne sürdükleri bilinmektedir. Ancak Moskova, Lenin'in milletler politikasını Türkistan'da da aynen uygulamak düşüncesinde olduğu için, bu tür fikirleri geri çevirmiş ve Türkistan'da özerk cumhuriyetler ve vilayetler kurmaya başlamıştır. Bu durum karşısında Kırgız aydınları da Kırgız kültür ve tarihinin çok daha eski devirlere dayandı̆̆ını ileri sürerek, kendi millî özerk vilayetlerinin kurulmasına çalışmışlardır. Ancak böyle bir millî devlet kurma davası çerçevesinde Kırgızistan'da çeşitli gruplar ortaya çıkmıştır.

Bu bağlamda 1920’li yıllarda Kırgızistan'da “Otuzcular Mektubu”» adlı hareket ve SSCB'de büyük yankı uyandıran "Ur-Tokmok" davası gibi siyasî grupların

2 Kültür Devrimi -1920('li)-1930'lu yıllarda SSCB'de V. Lenin'in sosyalizmi yerleştirme planına göre sosyalist sanayileşme, tarımı kolhozlaştırma ve toplumu dönüştürme yönünde yürütülen faaliyetlerin adıdır. 1917 Sosyalist Ekim İhtilali’nin başarısı sonrasında burjuva kültürünün yerini sosyalist kültürün aldığı kabul edilmiştir. Kültür Devrimi ile Sovyet kültürünü yayma, dine karşı mücadele, halkın tamamını okur-yazar kılma; bilim, edebiyat ve sanatı geliştirme amaçlanmıştır.

İ̧ Savaş - 1917-1923 yılları arası, Sovyet dönemi literatüründe "İç Savaş" (veya Sivil Savaş, Rusça; Grajdanskaya Voyna) dönemi olarak adlandırılmaktadır. Sivil Savaş sırasında SSCB'de Sovyet yönetimini destekleyen Kızıl Ordu ile eski Çarlık rejimini destekleyen anti-bolşevik Beyaz Ordu arasında çatışmalar yaşanmıştır. Beyazlar, silah yoluyla Bolşevikleri devirmeyi, kaybettikleri yönetim yetkilerini, sosyo-ekonomik hak ve imtiyazlarını yeniden elde etmeyi amaçlamışlardır. Siyasî görüşleri anti-bolşevik olan Beyaz muhafizlar, savaş sonunda mağlup edilmiştir. Orta Asya'da ise yeni rejime karşı mücadele, hem Beyaz Ordu kuvvetleri, hem de ağırlıklı olarak Basmacılar tarafindan yürütülmüşür.

4 “Otuzcular Mektubu” - 1925’te 30 kadar yerli Kırgız devlet adamının Komünist Parti'nin Kara Kırg1z Özerk Vilayeti Komitesi birinci sekreteri Mihail Kamenskiy’in yürüttüğü siyasetini protesto ederek SSCB üst yönetimine yolladıkları mektubundan dolayı ortaya çıkmış bir siyasî grubun ismidir. Kırgızistan'da Bolşeviklerin diktatörlük eğilimini kınayan ilk muhalefet niteliğindeki "Otuzcular Mektubu" Kremlin tarafindan milliyetçilik hareketi olarak değerlendirilmiştir.

"Ur-Tokmok" - Türkçesi Döv-Tokmak, yani 'sopayla döv' anlamındadır. 1926 y1lında Rahmankul Hudaykulov grubundakilere karşı açılan davanın ismidir. R.Hudaykulov ve grubundakiler siyasî 
faaliyetleriyle ilgili çeşitli olaylar yaşanmıştır. "Otuzcular Mektubu” muhalif hareketinin başında devlet adamı Abdıkerim Sıdıkov bulunuyordu. "Ur-Tokmok" davası ise Rahmankul Hudaykulov'un liderliğindeki gruba karşı açılmıştı. Ne var ki, Sovyet rejiminin sonuna kadar, bu grupların gerçek amaçları ve tarihleriyle ilgili geniş çerçeveli objektif araştırmalar yapılamamıştır. Bağımsızlık sonrasında ise, bu grupların tarihini ve liderlerini ele alan birkaç makale ve monografi yayınlanmasına rağmen, bunlarda da Sıdıkovcular grubunun bağımsız Kırgız devletinin temelinin atılmasındaki rolü abartılı bir şekilde ele alınmış, Hudaykulovcuların rolü ise olduğundan küçük gösterilmeye çalışılmıştır. Bu zamana kadar tarihçilerin eserlerinde Hudaykulov-Babahanov grubunun sanki Kırgızların SSCB bünyesinde özerklik almasına karşı faaliyet yaptı̆̆ı hakkında görüş ağırlık kazanmaktadır. Ancak bu görüşün tam olarak doğru olmadığını makalede ilk defa göstermeye çalıştık. Çalışmada Sıdıkovcu ve Hudaykulovcu grupların faaliyetleri, her iki grubun millî özerk cumhuriyet kurma konusundaki siyasî fikirleri temelinde mücadeleleri ve Moskova yönetiminin bu duruma yönelik tutumu ele alınacaktır.

\section{Moskova'nın Ģıkarları Işığında Gruplar Arası Mücadele}

Kırgızistan'da Sovyet rejiminin kuruluşunun ilk yılından itibaren 1920'li yıllar boyunca Komünist Parti’nin Kırgızistan şubesinde gruplar arası mücadeleler yaşandığı görülür. Özellikle birine Abdıkerim Sıdıkov’un, ikincisine ise Rahmankul Hudaykulov'un liderlik ettiği iki grup arasında sürüp giden çekişmeler ve tartışmalar, bu mücadelelerin en tipik örneği olarak gösterilebilir. Sovyet yönetimi tarafindan söz konusu iki grubun rekabeti, "boylar-arası mücadele" olarak değerlendirilme çabaları da olmuştur. Bağımsızlık döneminde ise tarihçi Zaynidin Kurmanov ise, bu iki gruba katılanların boy köklerini araştırarak, bunların boy menfaatini koruyan gruplar olmadıklarını, ideolojik ve siyasî sebeplerle bir araya geldiklerini ileri sürmüştür. Ona göre, bu mücadele boylar-arası çatışma değildi; çünkü aynı boyun temsilcileri her iki grupta da bulunuyordu. İki grubun boy yapısına bakıldığında, Hudaykulov'un taraftarları 1 uruk ve 3 boyun (Tınay, Solto, Sarıbagış ve Çerik) temsilcilerinden, Sıdıkov'un grubu ise 6 boyun (Solto, Sayak, Bugu, Kıpçak, Sarıbagış ve Adıgine) temsilcilerinden oluşuyordu. Bu iki grup, boy yapısı dışında, sınıf yapısına göre de ayrılmamıştı. Zîrâ bay-manap, orta halliler, batrak $k^{6}$ e fakir sinıfa mensup üyeler her iki grupta da bulunuyordu. Yani

argumanlarla değil, fizikî güç kullanmayı tercih eden " $U r$-Tokmok" terör örgütünü kurmak ve yasadış1 faaliyetlerde bulunmakla suçlanmışlardır.

6 Batrak - Rusça bir kelime olup 'zengin birinin yanında ücretle çalışan köylü' anlamına gelmektedir. 
sosyal ve boy bağlantıları açısından her iki grubun birbirinden farkı yoktu. Bunlar çlkarlarına, entelektüel durumlarına, meslekî faaliyetlerine, dünya görüşlerine ve halk nezdindeki sorumluluk derecelerine göre bir araya gelmişlerdi. Gruplaşma, daha ziyade iktidar mücadelesine dayanıyordu. Başka bir deyişle, iki grup arasındaki mücadele, siyasî elit tabakaların iktidar mücadelesiydi ${ }^{7}$.

İki grubun liderlerinden Abdıkerim Sıdıkov, 1889'da Pişpek uezdinde ${ }^{8}$ doğmuştur. Varlıklı bir ailenin çocuğu olduğu için iyi bir eğitim alan A. Sıdıkov, 1912-1917'de Rus Çarlığı'nın Pişpek uezdi dairesinde sekreter ve tercüman olarak çalışmıştır. 1917 Şubat Devrimi'nden sonra Pişpek uezdi komiser yardımcllğı görevinde bulunmuştur. Temmuz 1917'de Orenburg şehrinde Kazak aydınları tarafından millî demokratik bir devlet kurmayı hedefleyen "Alaş" partisi kurulmuştu. Aynı yıl, Abdıkerim Sıdıkov, İ. Arabayev, K. Tınıstanov ve başka Kırgız aydınlarıyla birlikte, Pişpek'te "Alaş" partisinin Kırgızistan şubesini açmış ve bu şubenin başkanlığını yapmıştır. A.Sıdıkov, 1919-1920'de Yedi-Su vilayeti Müslüman Bürosu başkan yardımcısı, 1921'de önce Sovyetlerin Yedi-Su Vilayeti Yürütme Komitesi başkan yardımcısı, sonra başkanı olmuş; 1922'de Türkistan Özerk Sovyet Sosyalist Cumhuriyeti (Türkistan SSC) İçişleri Halk Komiseri yardımcllğı görevlerinde bulunmuştur.

Abdıkerim Sıdıkov, 1922'de Özerk Dağlı Kırgız Vilayeti projesini savunan devlet adamlarından biri olarak Özerk Dağlı Kırgız Vilayeti organizasyon komisyonu başkanlığını üstlenmiştir. $\mathrm{Bu}$ proje, $\mathrm{SSCB}$ üst yönetimi tarafindan reddedilmiştir. 1924'te A. Sıdıkov, bu defa Kara Kırgız Özerk Vilayeti'nin kuruluşuna büyük katkı sağlayan bir devlet adamı olarak karşımıza çıkar. Otuzcular Mektubu girişiminden sonra siyasetten uzaklaştırılıp Frunze'den (günümüzde Bişkek) Taşkent'e sürgün edilmiştir. 1926-1932'de Taşkent'te yükseköğretim kurumlarında çalışmışır. 1932'de Kırgızistan'a geri çağrılmış ve burada Kırgız Özerk Sovyet Sosyalist Cumhuriyeti Devlet Planlama Dairesi başkan yardımcılığına getirilmiştir. 1933’te ise milli devrim karşıtı örgütün başkanlığını yaptığı suçlamasıyla hapsedilmiş, önce 10 sene sürgün cezası verilmiş, daha sonra

Zaynidin Kurmanov, Politiçeskaya Borba v Kirgızstane 20-e Godı, İlim Yay., Bişkek 1997, s. 90-91.

Uezd - Rus Çarlığı döneminde Türkistan'da vilayete bağlı ilçe. 
1938'de Repressiya ${ }^{9}$ zamanında tekrar yargılanmış ve ölüme mahkum edilmiştir ${ }^{10}$.

Sıdıkovcu grubunun seçkin temsilcilerinden birisi de, daha önce Ceditçilik hareketinin de önderlerinden devlet adamı ve aydın bir insan olan İşenalı Arabayev (1882-1933) idi. O, 1920-1923'te Yedi-Su bölgesinde "Koşçu” Birliği’nin "1 başkan yardımcılığı, 1924’te Kara Kırgız Özerk Vilayeti Bilim Komisyonu başkanlığı ve Kırgızca ilk süreli yayın olan Erkin-Too gazetesinin redaktörlügü görevlerinde bulunmuştu. 1926'da Bakü Türkoloji Kurultayı'na katılan I. Arabayev, birçok ders kitabının ve ilmî eserlerin de yazarıdır. İ. Arabayev, “Otuzcular Mektubu”nun hazırlanmasına aktif olarak katılmıştı. "Otuzcular Dilekçesi" olarak da bilinen bu muhalif girişimden sonra siyasetten uzaklaştırılmış; 1933'te tutuklanmış ve aynı yıl hapishanede hayatını kaybetmiştir. ${ }^{12}$ A. Sıdıkov ve İ. Arabayev dışında, bu grupta C. Abdrahmanov, I. Aydarbekov, S. Çonbaşev ve başka seçkin Kırgız devlet adamları bulunuyordu.

Diğger grubun lideri Rahmankul Hudaykulov ise, 1885 yılında ÇonKemin ilçesinde doğmuştur. Din adamı olan babası Hudaykul Atansartov, 1916 bağımsızlık mücadelesini yönetenlerden biriydi. R. Hudaykulov, 1918 yılında Komünist Parti’ye üye olmuştur. 1919-1920'de Komünist Parti'nin Narın şehir komitesi sekreteri görevine yükselmiş; 1921'de "Koşçu” Birliği Yedi-Su vilayeti şubesi başkanlığına atanmış; 1924’te Kara Kırgız Özerk Vilayeti kurulduktan sonra Kırgızistan "Koşçu” Birliği başkanlığını yürütmüştür. Daha sonra Sovyet Rusya Bakanlar Kurulu'nun, göçebe toplumları yerleşik hayata geçirmek üzere kurduğu özel komisyonun üyesi olarak çalışmıştır. 1926 yılında kendi grubundaki kişilerle birlikte "Ur-Tokmok" davasından yargılanmış ve Komünist Parti'den azledilerek hapsedilmiştir. 1929'da hapishaneden çıkan Hudaykulov’un sonraki

9 Repressiya - Latince kökünden “Repressiya”kelimesi bastırma, zulüm ifadesini bildirmektedir. SSCB'de devlet makamları tarafindan uygulanan cezalandırıcı eylem, ceza anlamındadır. 1917'de Sovyet yönetimi kurulduktan hemen sonra baskı tedbirleri uygulanmaya başlamıştır. SSCB'de hapis, sürgün, vatandaşlıktan mahrum bırakma, zorla çalıştırma, ölüm cezasına çarptırma gibi repressiya eylemleri icraata geçirilmiştir. Repressiya siyasetinin özellikle J. Stalin’in yönetimde bulunduğu dönemde (1923-1953) çok şiddetli bir hâl aldığı bilinmektedir. Tarih biliminde Büyük Terör olarak adlandırılan 1936-1938 döneminde ise Repressiya tüm devlet çapında acımasız bir şekilde en doruk noktasına ulaşmışır. Repressiya hareketinin icraası ve motifleri tüm SSCB'de olduğu gibi Sovyet Kırgızistanı için de aynıdır. 1937-1938 yıllarında Kırgızistan'da siyaset ve devlet adamları, memurlar, milli aydınlar, asker adamları gibi bir çok zümre repressiya kurbanı olmuşlardır.

10 Kirgız Tanhı, Mamlekettik Til cana Entsiklopediya Borboru Yay., Bişkek 2003, s.358.

11 "Koş̧u” Birliği - Koş̧̧ kelimesi, çiftçi anlamina gelmekte olup 1921 'de Türkistan'da kurulan köylü dayanışma örgütünü ifade etmektedir. 1924'te Türkistan'ın cumhuriyetlere bölünmesinden sonra Orta Asya Sovyet cumhuriyetlerinde "Koşçu” Birliği şubeleri kurulmuştur.

12 Kirgız Tarhh, Mamlekettik Til cana Entsiklopediya Borboru Yay., Bişkek 2003, s.114. 
hayatı hakkında bilgi bulunmamaktadır'3. O'nun da 1937-1938'de Repressiya kurbanı olduğu tahmin edilmektedir.

Hudaykulov'un grubunda ikinci sırada Düyşönalı Babahanov bulunuyordu. Düyşönalı Babahanov, kısa zaman zarfinda Kırgızistan'da üst seviyedeki devlet makamlarına kadar yükselmiştir. Devlet adamı D. Babahanov (1898-1938), 1918 yılında Komünist Parti üyeliğine kabul edilmişti. 1920-1922 yıllarında Tokmok Belediyesi Yürütme Komitesi sekreteri, "Koşçu” örgütü Yedi-Su Vilayeti Komitesi başkan yardımcısı, 1924-1926 yılları arasında Pişpek ve Komünist Parti Karakol İlçe Komitesi sekreteri, Sovyetler Birliği Bolşevik Komünist Partisi, Kırgız Vilayet Komitesi başkanı birinci yardımcısı ve ikinci sekreteri görevlerinde bulunmuştur. 1926 yılında ise, toplu mücadeleye ve "Ur-Tokmok" terör örgütüne katıldı̆̆ı suçlamasıyla partiden uzaklaştırılıp hapsedilmiştir. 1929 yılında serbest bırakılan Babahanov, Kazakistan'ın Cambıl ve Çimkent şehirlerinde fabrika müdürü ve iç ticaret bölüm başkanı olarak çalışmıştır. 1937 yılında, Repressiya döneminde tekrar tutuklanmış ve 1938'de hayatını kaybetmiştir ${ }^{14}$. Hudaykulovcu grupta R. Hudaykulov ve D. Babahanov dışında, I. Toyçinov, I. Hudaybergenov, K. Sarıbayev, K. Bapanov, M. Sarıbatırov ve başka temsilciler de yer alıyordu. Ancak her iki grubu desteklemeyen, onların mücadelelerine katılmayan üst düzey Kırgiz bürokratları (C. Sadayev, K. Tınıstanov, S. Karaçev, O. Aliyev, T. Aytmatov, S. Kulmatov, E. Esenamanov, T. Coldoşev vb.) da vardı ve bunlar tarafsız hareket ediyorlardi.

Sovyet dönemine kadar Sıdıkovcular, "Alaş’ın” Kırgız şubesi, "Şûrâ-yı İslâmiyye" ve "Solcu Eserler" (Solcu Sosyalist Devrimci Partisi) gibi demokratik partilerin üyeleriydiler; Hudaykulovcular ise, "Bukara" Birliği’nde bulunmuşlardır. Sonradan "Bukara" Birliğgi dağıtılmış ve Sovyet yönetimi tarafindan "Koşçu" Birliği olarak tekrar oluşturulmuştur. Hudaykulovcuların çoğu "Koşçu” Birliği üyeleriydi. Sıdıkovcu grubu, Sovyet yönetimine sadık, Rus Çarlığı döneminin eski millî aydın temsilcilerini ve eski Rus Çarlığı sömürge idaresinde hizmette bulunanları devlet yönetimine çekmeyi aktif bir şekilde destekliyorlardi; Hudaykulov grubundakiler ise, buna kesinlikle karşı idiler; Sovyet sınıf mücadelesi teorisine göre yönetime fakir kesimden insanların alınması konusunda Bolşevik siyasetini benimsiyorlardı.

13 Hudaykulov Rahmankul, http://www.centrasia.ru/person2.php?st=1066471235, erişim: 21/06/2018.

14 Babahanov Duyşenalı Babahanoviç, http://www.centrasia.ru/person2.php?st=106646982 1, erişim: 21/06/2018. 
Birinci grup kadro politikasında memurlarm kabiliyetine, ikinciler ise memurun sosyal kökenine önem veriyordu. Gruplar arasında sosyalist sistemi yeniden düzenleme temposu, Rus Çarlığı devrinde Rusya'dan göçerek Kırgızistan’a yerleşen Slav asıllı halka karşı tutum, Toprak-Su Reformu ${ }^{15}$, Komünist Parti ve Sovyetlerin rolü ve devlet yapısı gibi meselelerde de fikir ayrılığı bulunuyordu. Bu noktada iki gruptan birinin tutumunu idealleştirmek doğru olmaz. Her iki grubun üyeleri de kendilerini Komünist sayıorlardı, her iki grubun tutumlarında da demagoji, popülizm ve siyasî menfaat kaygıları bulunuyordu. Bu bakımdan, onları Sovyet karşıtı olarak değerlendirmek de yanlış olurdu; çünkü bu mücadeleler daha çok fikir ayrılığı esaslıydı ${ }^{16}$.

Bu iki grup arasındaki mücadele, özellikle Özerk Dağlı Kırgız Vilayeti (1922) ve Kara Kırgız Özerk Vilayeti (1924) projesi konularında sert bir şekilde devam etmiştir. Bu mücadelenin önemli sebeplerinden birisi de, yeni kurulacak olan vilayetlerdeki başlıca devlet makamlarının iki grup üyeleri arasında paylaşımı meselesi idi. 1918'de kurulan Türkistan SSC içinde Kırgızlar Yedi-Su, Sır-Derya ve Fergana vilayetlerinde azınlık olarak yaşıyorlardı. Moskova yüksek yönetimi, Çarlık Rusya döneminden beri Kırgız ve Kazakları aynı halk olarak karıştırıyorlardı. Kırgız (Kazak) ${ }^{17}$ Özerk Sovyet Sosyalist Cumhuriyeti'nin kuruluş aşamasında Yedi-Su ve Sır-Derya vilayetlerinin Kırgız (Kazak) ÖSSC'ye katılması ihtimali ortaya çıkmıştı. Bu sebeple 1922'de A. Sıdıkov, I. Arabayev ve C. Abdrahmanov gibi Kırgız aydınları tarafindan Kırgızistan’ın kuzeyinde Rusya Sovyet Federatif Sosyalist Cumhuriyeti’ne (RSFSR) bağlı Özerk Dağlı Kırgız Vilayeti kurulması

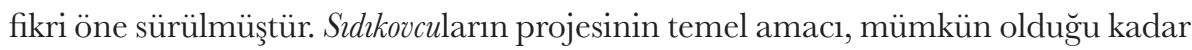
kısa bir süre içinde Türkistan’ın Yedi-Su ve Sır-Derya bölgelerindeki Kırgızların yaşadıkları ilçeleri de içine alan millî Özerk Dağlı Kırgız Vilayeti’nin kurulması

15 Toprak-Su Reformu - 1920'lerde Sovyet Türkistanı'nda olduğu gibi Kırgızistan'da da Toprak-Su reformu yapılmıştır. Reformun hedefi, bölgeye 1917 Ekim Devrimi'nden önce gelen Rus köylüleriyle yerli halkın toprak ve sudan eşit şekilde yararlanmasını sağlamak; zenginlerin ellerinde bulunan fazla toprakları fakirlere dağıtmaktı. Bu reform, Kırgızistan'da iki safhada gerçekleştirilmiştir: 1921-1922 yıllarında ülkenin kuzeyinde uygulanan bu reform, güneyde Basmacı Hareketinin devam etmesi sebebiyle daha sonra, 19271928 yıllarında hayata geçirilebilmiştir. Kolektif çiftliklerin ortaya çıkmasına Toprak-Su Reformunun büyük katkısı olmuştur.

16 Zaynidin Kurmanov, Natsiyonalnaya İntelligentsiya 20-30 Godov: Vklad v Vozrojdeniye Gosudarstvennosti Kirglzskogo Naroda i Borbu s Totalitarno-Avtoritarmm Rejimom, Bişkek 2005, s. 177.

17 Bu dönemde Kazaklar Ruslar tarafindan Kırgız olarak adlandırılmışır. 1920 yılında başkenti Orenburg olan Kırgız ( yani Kazak) Özerk Sovyet Sosyalist Cumhuriyeti teşkil edilmiştir. Kırgız Özerk Sovyet Sosyalist Cumhuriyeti 1925 yllından itibaren Kazak ÖSSC olarak isimlendirilmeye başlar. 1936'da ise Kazak Sovyet Sosyalist Cumhuriyeti statüsünü alır. 
idi. Sıdıkov’un projesi, çoğunluğu Özbek asıllı olan bürokratların işine geliyordu; çünkü bu durumda Kırgızistan’ın güneyini içine alan Fergana vadisinde Kırgızların yaşadıkları ilçeler Özbekistan sınırları içerisinde kalacaktı. Mart 1922'de Türkistan Komünist Partisi Merkez Komitesi tarafından, Özerk Dağlı Kırgız Vilayeti’nin kurulması konusunda bir karar alınmış; hatta aynı sene Temmuz ayında Dağlı Kırgız Vilayeti'nin kurulmasına yönelik hazırlık kurultayı bile düzenlenmişti.

Rahmankul Hudaykulov'un başında bulunduğu grup, Özerk Dağlı Kırgız Vilayeti projesine karşı çıkmıştır. R. Hudaykulov, 1922'de Rusya Komünist Partisi Merkez Komitesi’ne yazdığı bir mektupta, Özerk Dağlı Kırgız Vilayeti projesinin hayata geçirilmesinin henüz erken ve uygun olmadığını savunmakta idi $^{18}$. R. Hudaykulov’un Moskova’ya yolladığı söz konusu mektuptan anlaşılacağı üzere, kendisi özerk statülü ayrı bir Kırgız devletinin kurulmasına tamamen karşı çıkmamıştı; bugünkü Kırgızistan’ın sadece Kuzey bölgelerini içine alan bir millî Kırgız devletinin kurulmasını henüz erken buluyordu. Bugünden bakıldığında, kurulacak devletin bugünkü Kırgızistan’ın hem güneyini ve hem de kuzeyini kendi sınırları içine almayı hedefleyen R. Hudaykulov'un görüşünün daha doğru olduğu görülür. Ancak Moskova yönetimi, bölgedeki millî özerk cumhuriyetler arasında bir denge sağlamak maksadıyla bu projeyi durdurdu. J. Stalin, Dağlı Kırgız Vilayeti projesi önerisini, milli burjuva hareketi olarak değerlendirerek geri çevirme talimatı verdi. Bir az da bu sebeple olmalıdır ki, Sovyet dönemi tarihçiliğinde 'Dağlı Kırgız Vilayeti Kurma Projesi', burjuvazi milliyetçiliği teşebbüsü olarak görülmüş ve olumsuz değerlendirilmişti.

Türkistan'ı millî cumhuriyetlere ve vilayetlere bölme teklifi, 16 Eylül 1924'te Türkistan Sovyet Sosyalist Cumhuriyeti Merkez Yürütme Komitesi olağanüstü oturumunda, yine aynı yıl 14 Ekim'de II. Tüm Rusya Merkez Yürütme Komitesi toplantısında ve 27 Ekim'de SSCB Merkez Yürütme Komitesi toplantısında Lenin'in milletler politikası doğrultusunda onaylanmıştır. Böylece 14 Ekim 1924’te RSFSR'e bağlı Kara Kırgız Özerk Vilayeti kurulur. Kara Kırgız Özerk Vilayeti'nin (KKÖV) kuruluşu aşamasında, vilayetin hangi cumhuriyetin içinde bulunması gerektiği meselesi ortaya çıkmış ve bu husus Sıdıkov ve Hudaykulov grupları arasında gerginlik yaşanmasına yol açmıştır. Hudaykulovcular, KKÖV'nin Kazak Sovyet Sosyalist Cumhuriyeti'ne, Sidıkovcular ise Rusya Sovyet Federatif Sosyalist Cumhuriyeti’ne bağlanmasını desteklemişlerdir. Tarihçi C. Cunuşaliyev,

18 Rusya Sosyal-Siyasî Tarih Devlet Arşivi (RGASPI), fon. 62, liste.2, dosya. 43, s. 4-6. 
R. Hudaykulov'un boyunun Kazak kökenli olması sebebiyle ${ }^{19}$, onun bu tavrını şahsî gurur ve iktidar hursına bağlamaktadır. Hudaykulov, muhtemelen Kazak devlet adamlarının desteğini alarak devlet yönetiminde üst görevlere yükselmeyi planlamıştı ${ }^{20}$. 1924'te Kara Kırgız Özerk Vilayeti kurulduktan sonra Kırgızistan Komünist Partisi, devlet üst yönetimi ve devlet makamları teşkil edilmiş; bu makamlara hem Sıdıkov ve hem de Hudaykulov "partileri” temsilcileri getirilmiştir.

\section{“Otuzcular Mektubu" veya "Otuzcular Dilekçesi"}

1920'li ve 1930’lu yllarda Moskova Komünist Partisi Merkez Komitesi'nin inisiyatifiyle, bölgelere yetenekli devlet memurların görevlendirme bahanesiyle Türkistan'a Rus asıllı bürokratlar gönderme siyaseti takip edilmiştir. 19251932 yılları arasında Kırgızistan'a genellikle Rus ve Yahudi asıllı 500'den fazla devlet memuru gönderilmiştir. Bunların çoğu Kırgızistan'ın sosyal ve ekonomik kalkınmasına önemli katkı sağladığı halde 1937-1938 yıllarında Repressiya kurbanı olmuştur. Fakat merkezden gönderilen bazı idareciler için taşra görevleri, politik kariyer aracı olarak kullanılıyor ve sadece istikbalde yüksek görevlere sıçrama tahtası olarak görülüyordu. Bu valiler, bölgenin şartlarını ve bölge halklarının dilini bilmiyor; yerli halkın gelenek, görenek ve kültürüyle ilgili temel bilgilerden habersizlerdi. Moskova'dan uzak bölgelere gönderilen Bolşevik yöneticileri, Komünizmin sınıf mücadelesi anlayışı doğrultusunda hareket ediyor, gittikleri bölgelerin değerlerini dikkate almayan faaliyetlerde bulunuyorlardı. Başka bir deyişle, görev yaptıkları bölgeleri çoğunlukla ideolojik anlayışları doğrultusunda yönetmeye çalışıyorlardı. Moskova'dan Kırgızistan'a, Kırgızistan Vilayet Komitesi genel sekreterliği görevine tayin edilen Mihail Kamenskiy de bu zihniyete sahip valilerden biri idi ${ }^{21}$.

Mihail Kamenskiy (1889-1963), 1908 yllında Bolşevik partisine üye olmuştu. 1924-1925 y1llarında Komünist Parti'nin Kara Kırgiz Özerk Vilayeti Komitesi genel sekreteri olarak çalıştı. 1925-1941 yılları arasında Rusya'da, Doğu Kafkasya'da vilayet parti örgütlerinde görev aldı. 1941 yılında tekrar Kırgizistan'a döndü ve 1944 yllına kadar Krasnaya Reçka Makine-Traktör İstasyonu müdürlüğü görevinde bulundu.

19 Rahmankul Hudaykulov, Kırgızlara karışan Kazakların Abla boyunun temsilcisiydi; yani Sarıbagı̧̧ boyunun Tinay urugunun Abla kolundand.

20 Djeniş Djunuşaliyev, Vremya Sozidaniya i Tragediy, İlim Yay., Bişkek 2003, s. 93.

${ }^{21}$ Djeniş Djunuşaliyev, a.g.e., s. 79. 
Yeni göreve gelen M. Kamenskiy ile Sidıkovcular arasında başlangıçta ilişkiler iyiydi. M. Kamenskiy, Kırgızistan'a geldikten sonra şahsî iktidarını pekiştirmeye çalışmışır. Onun bu amacına kendi aralarında mücadele eden Sıdıkov ve Hudaykulov grupları engel olmuşlardır. Hudaykulovcular, kendilerini, baymanaplara karşı mücadele eden fakir sınıfin temsilcileri olarak gösteriyorlardı. Hudaykulov grubundakiler, rakipleri Sidıkovcuları bay-manap, Çarlık Rusyası sömürge yönetiminde devlet memuru görevinde bulunanlar ve geçmişte "Alaş" partisi üyeleri olarak göstermeye çalışmışlardır. M. Kamenskiy, Hudaykulovcuların bu iddiâlarını çok inandırıcı bulmuş ve bu durum onun Hudaykulovcuların tarafinı tutmasına sebep olmuştur. M.Kamenskiy, Hudaykulov grubunun gerçekten fakir sınıfın çıkarlarını savunmak için mücadele ettiğine inanarak yanlış fikre kapılmıştı ${ }^{22}$. Oysa gerçekte her iki grupta da varlıklı tabakadan gelen kimseler bulunuyordu ve her iki grup da yönetimi ele geçirmek için mücadele ediyordu.

M.Kamenskiy, iki tarafi uzlaştırmak yerine "böl, parçala ve yönet" prensibiyle hareket ederek olaya Hudaykulov lehine müdahil olmuştu. Kamenskiy, Hudaykulov'u sadece sosyal kökeninden dolayı desteklemiyordu. Aslında, Hudaykulov, onun için, Sidıkovcularla mücadelede sâdece bir alet durumunda idi. Sıdıkov grubunda entelektüellik açısından en donanımlı insanların toplanmış olması, Kamenskiy'in şahsî iktidarına tehdit oluşturuyordu. Kamenskiy'in bizzat kendisi dahi sadece ilk okul tahsili görmüş birisiydi. Oysa, Sidkkovculara nazaran düşük eğitimli Hudaykulov ve taraftarları kendisi için daha az tehlike teşkil ediyordu. R. Hudaykulov ise M. Kamenskiy'in desteğiyle kendi amaçlarına ulaşmaya, yâni devlet makamlarında üst mevkilere yükselmeye çalışmakta idi ${ }^{23}$.

A. Sidıkov'un taraftarları, R. Hudaykulov grubunu destekleyen M. Kamenskiy tarafindan Kırgızistan'ın yüksek yönetim makamlarından uzaklaştırlır ${ }^{24}$. M. Kamenskiy'in grupları birbirine düşürme siyaseti sonucunda, grupların karşılıklı mücadeleleri daha da şiddetlendirmiş ve kamuoyu önünde ikili gerginliği kaçınılmaz hâle getirilmişti. M. Kamenskiy'in başında bulunduğu Kırgız Vilayet Komitesi'nin bu hatalı politikası, Sidıkovcularm (Otuzcularm) protestolarma yol açmıştır.

22 V. Ploskih, Z. Kurmanov ve U. Begaliyev, Kirgızstandın Uluttuk Lideri Abdıkerim Sidıkov. Door, Insan, Tagdrr, Uçkun Yay., Bişkek 1999, s. 115.

23 Zaynidin Kurmanov, Natsiyonalnaya Intelligentsiya.., s. 213.

24 Meselâ 1925’te C. Abdrahmanov, Kırgizistan Vilayet Komitesi ikinci sekreteri görevinden; I. Aydarbekov, Kara Kırgız Özerk Vilayeti İhtilal Komitesi başkanlığından azledilmiştir. Bunların dışında S. Çonbaşev, A. Sıdıkov, İ. Arabayev ve başka devlet adamları da görevinden azledilmişlerdir. 
Haziran 1925'te 30 kadar yerli Kırgız devlet adamı, Komünist Parti Merkez Komitesi'ne, Komünist Parti'nin Orta Asya Bürosu'na ve SSCB Milletler Kurulu'na Otuzcular Mektubu olarak bilinen dilekçeyi yollarlar. Otuzcular, dilekçelerinde Kamenskiy'in başında bulunduğu Kırgız Vilayet Komitesi'nin çalışma tarzını, yöntemini, yetersiz ekonomik faaliyetlerini ve kadro siyasetini eleştirmişlerdi. Mektubu imzalayan Kırgız devlet adamları, parti içinde artmakta olan bürokratikleşmeyi önlemek ve demokrasiyi genişletmek istiyorlard ${ }^{25}$. Bu, Komünist Parti'nin Kırgızistan Vilayet Komitesi'nin dikta eğilimine karşı açı bir protesto idi. Otuzcularn tespiti konusunda OGPU'nun ${ }^{26}$ vilayet şubesi aktif rol üstlenmiştir. OGPU, her iki grupta yer alan Kırgiz siyaset adamlarının özgeçmişleriyle birlikte, kendileri hakkında her türlü bilgiyi toplamış ve Kırgız asıllı üst düzey bütün bürokratlarla ilgili gizli raporlar hazırlamıştı.

Otuzcular Dilekçesi'ni araştırmak üzere Komünist Parti Merkez Kontrol Komitesi Orta Asya Bürosu üyesi Zelikson, Komünist Parti Merkez Denetleme Komitesi Orta Asya temsilcisi Mancara, Orta Asya Bürosu üyesi Pavlovskiy, Özbekistan Komünist Partisi Merkez Denetleme Komitesi başkanı Mavlyanbekov ve Türkmenistan Komünist Partisi Merkez Komitesi üyesi Mamedov'un yer aldığ Orta Asya Bürosu Özel Komisyonu oluşturmuştu. Söz konusu komisyon üyeleri 1925 Haziran ayı sonunda Frunze şehrine gelirler. Komisyon, ayrı ayrı görüşme yapmak için ilk önce Otuzcular grubunun bir listesini oluşturdular. Ardından her bir üye ile ayrı ayrı görüştüler. Tek tek yapılan görüşmenin maksadı, muhalefetin gözünü korkutmaktı. İlk önce Vakas Muratov dayanamadı ve 29 Haziranda kendisinin suçlu olduğunu kabul ederek pişmanlığını bildirir ve Kırgız Vilayet Komitesi'nden kendi imzasının geçersiz sayılmasını rica eder. Ardından 2-3 kişi daha (Akılbekov, Abukanov, Aşurov) aynı şekilde Vakas Muratov’u izler.

Otuzcular Dilekçesi, bu özel komisyon tarafindan, "bay-manap unsurlar tarafindan Komünist Partisinnin ve Sovyet devletinin siyasetine karşı gerçekleştirilmiş̧ bir milliyetçilik hareketi”" olarak değerlendirilmiştir. Komünist Partisi’nin Orta Asya Bürosu Komisyonu, muhalefetin böyle bir dilekçe yazması hususunda Kırgız Vilayet Komitesi yönetimini de suçlu bulur; M. Kamenskiy'in Kırgız asıllı devlet adamlarına karşı yanlış politika yürüttüğü, iki grubu birbirine karşı kışkırttığı hükmüne varır. Söz konusu komisyon, Kırgiz Vilayet Komitesi’nin bütün belgelerini araştırıp

25 Kirgzzistan Cumhuriyeti Siyasî Belgeler Merkez Devlet Arşivi (KC SB MDA), fon. 10, liste.1, dosya. 31, s. 4-9.

26 OGPU - Rusçadan Obyedinennoye Gosudarstvennoye Politiçeskoye Upravleniye kelimelerinin kısaltılmasıdır. 1922-1934 yıllarında SSCB Halk Komiserler Sovyeti’ne bağlı Birleşmiş Devlet Siyasî Başkanlığı'nın adıdır. Siyasî gizli servis niteliğinde olan OGPU'nun görevleri, devlet karşıı siyasî ve ekonomik faaliyetleri önlemek, bastırmak, devlet güvenliğini sağlamak; kaçakçlıkla ve izinsiz sınırları geçenlerle mücadele etmek idi. 
incelemiş ve tuttuğu raporda Kırgız Vilayet Komitesi'nin resmî yazışmalarının Kırgız dilinde yetersizliği, eğitimde geride kalındığı, fakir kesimden kişilerin devlet görevlerine atanması işlerinde eksikler bulunduğu gibi noktaların da altını çizmiştir. M. Kamenskiy ise, Moskova'da eğitim seviyesini yükseltmesi gerekçesiyle görevden uzaklaştırılmıştır ${ }^{27}$. Orta Asya Bürosu Komisyonu, Komünist Partisi'nin Kırgızistan şubesini daha da Bolşevikleştirmek amacıyla yeniden yapılandırma çalışmalarını hızlandırmıştır.

Bu siyasî olaya son noktayı, 17 Ağustos 1925’te Kırgız Vilayet Komitesi'nin II. Olağanüstü Genel Kurulu koymuştur. Genel Kurul, Orta Asya Bürosu Özel Komisyonu'nun ulaştığı sonuçların doğru olduğu kanaatine varmıştır. Otuzcular Dilekçesini imzalayanların hepsine ağır kınama, Komünist Partisi üyeliğinden ihraç etme veya bulundukları görevlerinden azletme şeklinde cezalar verilmiş, A. Sıdıkov gibi bazıları ise Kırgızistan dışına sürgün edilerek cezalandırılmıştır.

\section{"Ur-Tokmok" Olayı}

Daha önceleri destek görmesine rağmen, Kırgızistan’da bu sefer cezalandırma sırası 1926 yılında "Koşçu” örgütü lideri R. Hudaykulov'un grubuna gelmiştir. R. Hudaykulov grubu, Ağustos 1925’te fakirleri korkutmak için Pişpek bölgesinde Sovyet karşıtı Ur-Tokmok terör örgütünü kurmak ve ağır cinayetler işlemekle suçlanmışlardır. Yasadışı kurulmuş Ur-Tokmok örgütü, Pişpek, Karakol ve Narın bölgelerine bağlı ilçelerde faaliyet gösteriyordu. R. Hudaykulov ve D. Babahanov, resmî görevlerinden istifade ederek devlet makamlarına kendi adamlarını yerleştirmek, manaplarla işbirliği yapmak, manapları hapis cezasından ve vergiden muaf tutarak Sovyet yasalarına aykırı davranmakla itham edilmişlerdir ${ }^{28}$.

Aslında Ur-Tokmok siyasî bir örgüttü. Örgütün idarî yapısı, para sandığı, hatta kendi siyasî programı bulunuyordu. Hudaykulovcuların hepsine, gruplar arası mücadeleyi körüklemek ve özellikle seçim zamanlarında fakirleri korkutmak için Ur-Tokmok örgütünü kullanmak; halkı korkutma, ağır vergiler ödetme, rüşvet alma, haydutluk etme ve böylece sosyalist sistemin pekişmesini engelleme suçları yöneltilmiştir. Sovyet yönetimine zarar verdikleri öne sürülen bu grup mensuplarının çoğu, Hudaykulov ve Babahanov başta olmak üzere, 1926'da Komünist Partisi üyeliğinden atılarak hapsedilmişlerdir ${ }^{29}$.

27 Zaynidin Kurmanov ve Erk Sadıkov, Sıdıkov. Liçnost i İstoriya, Şam Yay., Bişkek 2002, s. 151-152.

28 Rusya Sosyal-Siyasî Tarih Devlet Arşivi (RGASPI), fon. 121, liste.1, dosya. 38, s. 161-166.

${ }^{29}$ Kirgzzstandon Tanhı, Cilt.3, Kut-Ber Yay., Bişkek 2016, s. 227; Dj. Malabayev, Ukrepleniye Sovetov Kirgizii 
Şubat 1927'de Frunze şehrinde başlayan Ur-Tokmok davasının görüldüğü mahkeme duruşması iki hafta sürmüştür. Söz konusu davayı Moskova'dan Kırgızistan'a gelen Rusya Sovyet Federatif Sosyalist Cumhuriyeti Yüksek Mahkemesi bizzat yürütmüştür. Mahkemede, Hudaykulov grubuna mensup 17 kişinin dosyası incelenmiştir. 17 kişinin dosyası incelenmesine rağmen aslında hedef 2 kişi (R. Hudaykulov ve D. Babahanov) idi. Bunları yargılama direktifini doğrudan Komünist Parti Merkez Komitesi Siyasi Bürosu vermiştir. Aslında bu yargılama, kararı önceden belirlenmiş önyargılı bir yargılama idi. Söz konusu dava, bütün SSCB çapında büyük yankı uyandırdı. Sovyet yönetiminin ilk on yıllığında, SSCB'de ilk defa yüksek mevkilerde çalışan parti ve devlet adamları açık duruşma usulü ile yargılanmakta idi. Bu dava, hem Moskova'daki merkezî basında hem de yerli basında geniş olarak yer almıştır. $\mathrm{O}$ sırada 41 yaşında bulunan R. Hudaykulov'un ve 29 yaşındaki D. Babahanov'un isimleri, süreli basın-yayın organlarında da ön plana çıkartılmıştı.

Moskova yönetimi, hakemlere tanıklardan bu konudaki Kremlin siyaseti ışı̆̆ında uygun ifadelerin alınması hakkında talimat vermiştir. Böylece önce suçların vâki olup olmadığına bakılmaksızın, tanıklar, yönetime uygun ifadeler vermeye zorlanmışlardır. Hatta istenen nitelikte bilgi ve ifade vermeyen tanıklardan birisi mahkeme salonunda tutuklanmıştır. Düyşönalı Babahanov'a göre daha tecrübeli olan Rahmankul Hudaykulov, "Proleter mahkemenin kendisiyle ilgili alacă̆ herhangi bir kararn doğru olacağgn ve bunu aynen kabul edeceğini" önceden bildirmiş ve mahkemede suçlu olduğunu itiraf etmiştir. Düyşönalı Babahanov ise, sürekli, hiç çekinmeden kendisinin suçsuz olduğunu savunmuştur ${ }^{30}$. Neticede Hudaykulov'a yedi, Babahanov'a ise on sene hapis cezası verilmiştir. 1929'da cezaevinden serbest bırakılan Hudaykulov ve Babahanov'a, Kırgızistan sınırları dışında çalışma hakkı tanınmıştır.

1927'deki Hudaykulov-Babahanov davası sonunda Komünist Partisi'nin Kırgızistan şubesi "sosyal yönden yabancı unsurlardan" temizlenmiş olur. Kırgızistan tarihinde büyük yankı uyandıran Hudaykulov-Babahanov davasıyla, kim olursa olsun, bir parti Sovyet yetkilisinin yargılanıp hapse atılabileceği uyarısı verilmiş oluyordu. On yll sonra, 1937'de, bu Frunze örneği, yani devlet adamlarının tutuklanması ve yargılanması, Sovyetler Birliği'nin tamamında geniş̧ çapta görülecekti.

v Period Stroitelstva Sotsializma (1917-1937 gg.), İlim Yay., Frunze 1969, s. 350-351.

$30 K C S B M D A$, fon. 10, liste.1, dosya. 28, s. 219. 


\section{Sonuç}

Eylül 1925'te M. Kamenskiy'in yerine Komünist Partisi'nin Kırgizistan Vilayet Komitesi Sekreterliğine tayin edilen N. Uzyukov (1896-1937), Kırgızistan'da durumu normalleştirmeyi başarmıştır. N. Uzyukov, Kırgızların gelenek ve göreneklerini, manaplık teşkilatını dikkatli bir şekilde araştırdığı için gruplar-arası çatışmaların derinleşmesini önleyebilmiş; Kırgızistan'daki üst düzey devlet makamlarında kadro değişimine gitmiştir.

Hem Sidıkovcu (sağcı) hem Hudaykulovcu (solcu) grup üyeleri, 1920'li yıllarda Kırgizistan'da siyasî süreçlere aktif olarak katılmışlar ve ülkenin gelişmesine belli ölçüde katkıda bulunmuşlardır. Fakat Kremlin, iktidarı tamamen Kırgız asıllı bürokratların ellerine bırakmak istemiyordu. $\mathrm{Bu}$ sebeple Bolşevikler tarafindan önce sağcllar (Otuzcular Mektubu), sonra solcular (Ur-Tokmok) iktidardan uzaklaştırılmıştır. Bununla, hiçbir şart altında, hiçbir zaman, hatta Komünist Partisi’nin Kırgızistan şubesinin hatalı olduğu durumlarda bile, Komünist Partisi üyelerinin Merkez Parti Komitesi’yle herhangi bir fikir ayrllı̆̆ına düşemeyecekleri mesajı verilmişti. Kırgızistan'daki muhalif hareketlerin bastırılması ile Merkez'de muhalefetin bastırılması (Troçky, Buharin vs.) konusunda izlenen yol ve motifler aynıdır. Yani Merkez'deki demokratik eğilimli muhalefeti bastırma yöntemleri, millî bölgelerde de aynen uygulanmıştır. Böylece 1920'li yılların ortasında J. Stalin’in şahsî iktidarının kurulmasına doğru kesin adımlar atılmıştır. Sonradan 1937-1938 Repressiya döneminde hem Otuzcular Mektubu hareketine, hem Ur-Tokmok davasına katılan Kırgız siyaset ve devlet adamlarının çoğu, hatta tarafsız olanları da dâhil, hayatlarını kaybetmişlerdir.

Otuzcular Dilekçesi sadece eleştiriden ibaret olmasına rağmen "Komünist Partisi aleyhtar, milliyetçi ve bay-manaplar grubunun girişimi" olarak değerlendirilmiş̧tir. 1927'deki Ur-Tokmok davasinda Hudaykulov grubunun yok edilmesiyle Komünist Partisi’nin Kırgizistan şubesi içindeki hizipçiliğe son verilmiştir. Böylece 1920'li yılların ortasında Kırgizistan'da muhalefetin ve demokratik taleplerin bastırılmasıyla fikir özgürlüğüne son verilmiştir.

Sovyetler zamanında devletin ve halkın bütün başarıları sadece parti yönetimine ve liderlere atfedilmiştir. İdarî-kumandalı sistem şartlarında Sovyet cumhuriyetlerinde demokratik bakış açısına ve farklı şekilde düşünmeye izin verilmemiştir. Fikirleri rejimin taleplerine uymayan Sovyet kadroları ve özellikle aydınlar görevlerinden uzaklaştırılmıştır. Otuzcularn ve Hudaykulovcuların 
bastırlmasından sonra (1925-1927), Perestroyka yllarına kadar Sovyet Kırgizistan'ında KPSS’in (Sovyetler Birliği Komünist Partisi'nin) resmî politikasına karşı koyabilecek muhalif hareketler görülmemiştir. Sovyetler döneminde her iki olayın objektif şekilde araştırılması yasaklanmış; bütün materyaller OGPU tarafindan kaydedilmiş ve halktan gizlenmiştir. Günümüz açısından bakıldığında A. Sıdıkov ve R. Hudaykulov'ların başında bulunduğu grupların faaliyetlerini antisovyet ve devrim karşıtlığ olarak değerlendirmek doğru olmaz; çünkü bu mücadele, ülkede yerel iktidarda söz sahibi olmayı hedefleyen iki ayrı fikir grubunun mücadelesiydi.

\section{KAYNAKLAR}

Babahanov Duyşenalı Babahanoviç, http://www.centrasia.ru/person2. php?st=1066469821, Erişim: 21/06/2018.

Djunuşaliyev, Djeniş, Vremya Sozidaniya i Tragediy, İlim Yay., Bişkek 2003.

Hudaykulov Rahmankul, http://www.centrasia.ru/person2.php?st=1066471235, Erişim: 21/06/2018.

Kirgız Tarhh, Mamlekettik Til cana Entsiklopediya Borboru Yay., Bişkek 2003.

Kirgzzistan Cumhuriyeti Siyasî Belgeler Merkez Devlet Arşivi (KC SB MDA), fon. 10, liste. 1, dosya. 28; dosya. 31.

Kirgızstanden Tarhh, Cilt. 3, Kut-Ber Yay., Bişkek 2016.

Kurmanov, Zaynidin ve Sadıkov Erk, Sidıkov. Liçnost i İstoriya, Şam Yay., Bişkek 2002.

Kurmanov, Zaynidin, Natsiyonalnaya Intelligentsiya 20-30 Godov: Vklad v Vozrojdeniye Gosudarstvennosti Krrgzzskogo Naroda i Borbu s Totalitarno-Avtoritarnmm Rejimom, Bişkek 2005.

Kurmanov, Zaynidin, Politiçeskaya Borba v Kirgzzstane 20-e Godı, İlim Yay., Bişkek 1997.

Malabayev, Dj., Ukrepleniye Sovetov Kirgizii v Period Stroitelstva Sotsializma (1917-1937), İlim Yay., Frunze 1969.

Ploskih, V., Kurmanov Z. ve Begaliyev U., Krrgzzstandin Uluttuk Lideri Abdikerim Sidkkov. Door, İnsan, Tagdır, Uçkun Yay., Bişkek 1999.

Rusya Sosyal-Siyasî Tarih Devlet Arşivi (RGASPI), fon. 62, liste. 2, dosya. 43; fon. 121, liste.1, dosya. 38 . 